\title{
The Effect of Gender Differences on the Choice of Banking Services
}

\author{
Enav Friedmann ${ }^{1}$, Oded Lowengart ${ }^{2}$ \\ ${ }^{1}$ Bar Ilan University, Ramat Gan, Israel \\ ${ }^{2}$ Ben Gurion University, Beer Sheva, Israel \\ Email: friedme5@biu.ac.il,odedl@bgu.ac.il
}

How to cite this paper: Friedmann, E. and Lowengart, O. (2016) The Effect of Gender Differences on the Choice of Banking Services. Journal of Service Science and Management, 9, 361-377.

http://dx.doi.org/10.4236/jssm.2016.95041

Received: August 15, 2016

Accepted: October 7, 2016

Published: October 10, 2016

Copyright (c) 2016 by authors and Scientific Research Publishing Inc. This work is licensed under the Creative Commons Attribution International License (CC BY 4.0). http://creativecommons.org/licenses/by/4.0/ (c) (i) Open Access

\begin{abstract}
This paper presents a conceptual framework based on the evolutionary theory to explain gender differences when considering the saliency of various attributes in choosing a banking service. Unlike most studies that examined the importance of these attributes by asking respondents to rate them, we assessed the saliency of the attributes indirectly in a choice task among five real banks, hence examined the gender differences in a realistic choices process. Results from both studies supported hypotheses based on evolutionary theory in that functional considerations such as cost were more important for men than for women, while other service characteristics were salient for both genders. Implications for marketing strategies that target men and women differently are discussed.
\end{abstract}

\section{Keywords}

Psychological Gender Differences, Bank Choice Process, Cost, Personal Service, Evolutionary Theory

\section{Introduction}

Many service industries compete in the marketplace with relatively undifferentiated products. In order to maintain a competitive advantage, services need to improve their understanding of the wants and needs of different demographic groups and tailor the right value proposition to. Nevertheless, studies about the choice of banks based on their services have produced conflicting conclusions [1]. Some found no gender differences in the criteria used to select a bank [2]-[4], while others established that some features such as costs were more important to men [5]-[7], whereas women focused on other services [8] [9]. Assuming cost is an issue important to both genders. Banks often show their customers the costs for having an account in their bank either through 
comparative advertisements or third party publications (see Appendix A and Appendix B). For example, C. Bank illustrates the difference between the accrued costs for customers for having a checking account in different banks, emphasizing that there is a significant difference between their bank and other alternatives (see Appendix A). Given that the costs of having a checking account are not only the bank's fixed charges but also include activity-based charges, customers pay additional fees when depositing or withdrawing their money. Similarly, W. Bank's advertisement (see Appendix B) compares the costs associated with money transfers. These two examples provide all consumers with the factual information needed to make a rational decision that presumably fits their needs. In contrast, Appendix $\mathrm{C}$ and Appendix $\mathrm{D}$ present different arguments for the potential benefits of having a checking account, while both mention the benefits of the low costs and personal service of D. Bank (in the small letters). Appendix C's example is directed to men and highlights a rational approach to decision making by indicating the growth potential of the account. The example in Appendix D, however, is directed at women and emphasizes personal attention and affective aspects of the bank's services as opposed to stressing the arithmetic of the costs or focusing on the financial growth of the business.

These examples underscore an important dilemma for marketing managers in such service industries. Should they focus on a single area of their service such as low costs that benefits all customers or adopt a differentiated strategy that highlights different benefits for different gender segments? The answer to this question affects resource allocation and the effectiveness of the marketing strategy.

The purpose of this paper is to address this dilemma by providing a theoretical and empirical analysis of gender differences in choosing a financial service product such as a checking account. To resolve the conflicting results of previous studies, we use the evolutionary theory of men as hunters and women as gatherers to identify gender differences in the decision-making process with salient attributes leading to real choices rather than concentrating solely on the outcome or the order of importance of the factors when evaluating a single bank. We test our proposed approach using a descriptive field study in a choice context and an experimental study.

\section{Theoretical Background}

There are dozens of studies about the criteria people use to choose a bank. However, there are a limited number of comprehensive theories that explain the expected pattern of differences. Gender is often used as an easy segmentation tool, because marketing by gender is relatively simple, and the resulting segments are large enough to be profitable [10]. Using the evolutionary theory to explain the pattern of differences, we propose that men as hunters will focus on attributes such as costs, and women as gatherers who are more experientially and environmentally oriented, will focus on other aspects of the service such as the courtesy of the employees, and personal or professional service.

\subsection{Psychological Differences between the Genders}

The literature abounds with documented biological and sociological differences between men and women [11]. The most prominent and influential work is in the field of 
sociobiology, which attempts to explain all social behavior by evolution [12]. Studies have also explored the possible relationship between brain differences, sex hormones and behavior [13]. Supporters of this approach attribute gender differences to variations in work roles that evolved over millions of years, leading to changes in the brains of men and women [14].

The research has documented differences between the sexes with regard to a number of areas: cognitive (e.g., [15]), neurological (e.g., [16]) and sociological (e.g., [17]). Numerous studies have provided evidence that gender relates to customers' perceptions, attitudes, and preferences and purchases [18]-[22]. Thus, it is reasonable to assume that evolutionary theory will predict gender differences in the importance they attach to various aspects of a service being offered. In the hunter-gatherer theory, [23] argued that the source of unique, gender-specific characteristics is evolutionary in origin. This evolutionary point of view claims that sex differences originated as a function of the division of labor as hunters and gatherers. Women are considered to be more relational, expressive and contextual, whereas men are independent and stress their competency, task orientation and instrumentality. Therefore, men are "selective processors" who do not engage in comprehensive processing of all available information before making a decision. In contrast, women are "comprehensive processors" who attempt to assimilate all of the available information before rendering a judgment. Hence, women give equal weight to information they gather themselves and from others, encode more messages, and elaborate more extensively on specific claims [24]. Some researchers documented neurological differences stemming from differences in the brain structures, establishing that women process emotions and memories differently from men [25] [26]. In the same manner [16], claimed that a man's brain is more lateralized than a woman's, while in a female brain the corpus callosum that connects the hemispheres is thicker than in a male brain. As a result, women have a more holistic point of view, consider more elements when taking a decision and have greater contextual perception. Men are better at focusing on a target and are less contextual.

The evolutionary theory receives support from social psychology, which shows that women's self-image is based on the "self-in-relation" due to the importance they attach to the formation and maintenance of relationships [17]. In the same manner, men typically have an independent self-construal, whereas women typically have an interdependent self-construal [27]. Women also have a strong need for social interactions [28]. For example, within a formal online learning environment they send more interactive messages than men do and are more interested in all forms of assistance from others [29]. In the same manner, women are more likely than men to express concern about and responsibility for the well-being of others and less likely than men to support materialism and competition [30]. Recent biological evidence suggests an explanation for the notion of women as more communal by determining that the female hormone progesterone is negatively correlated to competitiveness [31] [32].

\subsection{Gender Differences in the Criteria for Selecting a Bank}

[33] points out that gender segmentation has increased as marketers have recognized 
that women are a lucrative market. Specifically, they realize that decisions about financial services involve both men and women, and financial decisions are sometimes made as a couple [3]. Hence, understanding the differences between males and females about banking services is critical for the bank's success [1].

Earlier research presented conflicting findings regarding the differential importance of personal service as a bank selection criterion. Some researchers have found that women are more concerned about the friendliness of the staff (for example: tellers who smile, feeling at home in the bank, polite bank personnel) [8] [34]-[36]. However, other researchers have claimed that men are more concerned about personal attention and service for gaining recognition (personal contact with bank officers, one-on-one communication or contact branch manager and banking by phone) [33] [35].

Similar conflicting results were found regarding convenience of the bank. Some research has showed that it is more important for women [1] [8]. Other researchers claimed it is more important for men [40]. Finally, some scholars have claimed that convenience is important for both: one stop banking and the ability to bank at any branch for men, and closeness to home or work place and parking facilities for women [35].

The results with regard to the relative importance of the safety of one's funds were also equivocal. [37] determined that this issue was more important for men, [34] found it was particularly important for women, and [38] claimed it was important for both. Similar conflicting results with regard to speedy and efficient service also emerged. Some research found it to be important for both men and women [37] [39]. [38] explained that this issue might be more important to women who still spent more time than men on childcare and were in a rush to finish their financial affairs and head home. Whereas [35] found that women only rated banks based on minimum waiting times, [40] claimed it was an important factor for men as well in choosing a bank.

In some studies, men were more concerned with service fees than women [5]-[7]. In others, women placed greater emphasis on financial benefits such as interest on saving accounts [8] [9] and prioritized channel saving and seeking value from credit card usage [40]. Finally, some scholars determined that costs such as minimum deposits or interest on loans were important factors for both men and women [39] [41].

Overall, the empirical results of past research are equivocal regarding the importance of cost, speed of services and efficiency and the importance of personalized services (interaction and recognition) for men and women. Such conflicting findings leave us without a specific, clear direction in terms of the factors that are important for men vs. women in choosing a bank.

The contradictory findings might be a result of differences in the samples, time periods, and methods. Most studies in bank selection criteria have been conducted by asking the respondents to note what traits were important to them when choosing a bank (e.g., [37] [38] [42]-[44]). Such direct questioning suffers from the flaws of social desirability; respondents might be unwilling or unable to report answers due to the desire to defend their ego or engage in impression management, resulting in data that are 
systematically biased toward the respondents' perceptions of what is correct or socially acceptable. These issues may lead to unwarranted theoretical or practical conclusions regarding purchase motivations [45].

The differential effect of gender on consumers' evaluation of a single brand cannot capture the differences in real selection situations, when one needs to choose between alternative brands, a more realistic situation [46]. Therefore, as detailed in the method section, in the descriptive study, we adopt an indirect approach to assessing the saliency of the various attributes of different banks by querying the participants about their perceptions about real banks and asking them to choose one of them. Our main study explores whether in a real choice setting, consumers make choices in accordance with the evolutionary theory.

Based on the literature describing women as more relational and men as more instrumental, we posited that men would choose banks based on functional considerations such as fees, and women would be more concerned with experiential considerations such as personal service and the courtesy of the employees. Thus, we constructed two hypotheses that we tested for the first time in a situation where the respondents had to make a real choice about which bank to use.

$\mathrm{H} 1$ - when choosing a bank, men will place greater emphasis on functional attributes such as costs than women will.

H2-when choosing a bank, women will place greater emphasis on experiential attributes such as personal service than men will.

\section{Method}

To test these hypotheses, we combined two methods: 1) a descriptive field study examined in a choice context and 2) an experimental study.

\subsection{Descriptive Study}

Our methodology uses a two-step approach. The first involves an exploratory study to determine the various service attributes consumers consider when choosing a bank. The second stage involves a descriptive research design that was conducted at two different levels. First, we determined how different five banks were one from one another at the aggregate level and which attributes contributed to this difference. Second, we conducted a data analysis at the group level based on gender differences.

Our modeling approach uses the multinomial logit model (MNL) that is based on choice theory and random utility modes [47]-[49]. We created a probabilistic description of checking account preferences based on the offerings of five existing banks (Bank H, Bank L, Bank M, Bank B, and Bank T). In order to capture gender heterogeneity, we applied the model to the two groups of consumers separately.

\subsubsection{Research Approach and Data}

To identify the attributes that consumers would consider when choosing a bank for a checking account, we created a focus group with 30 participants ( 16 men, 14 women, all 
undergraduate students in management in an Israeli university). Table 1 presents the final set of attributes that were identified in the literature review [50] as well as attributes derived from the focus group.

The second stage of the research, the descriptive phase, involved a survey-based approach in which we used a closed-end questionnaire to gather data from the respondents about their preferences and perceptions of the five banks. The criterion for participation was familiarity with the five banks we analyzed. Participants were asked to rate their responses on a 7-point interval scale with 1 representing a very low utility and 7 representing a very high utility. The questionnaire consisted of 16 items representing the attributes of a range of bank services which the respondents answered for each of the five banks (see Appendix E for the questions). For example, a respondent would be asked: "On a scale of 1 to 7, where 1 is very expensive and 7 is not expensive at all, how would you rate the fee for the service in this bank?" The reliability as measured by Cronbach's alpha for the five sets of questions ranged from 0.902 to 0.944 . Overall the reliability was 0.926 . In addition, respondents were asked to choose their most preferred bank. The order of the five brands was randomized in the survey.

Overall, the sample included 408 respondents selected through a stratified sampling procedure in a large Israeli city that allowed us to capture their heterogeneity with respect to their demographic characteristics. The sample contained 213 males and 195 females; 125 respondents had an income that fell below the national average, 115 were at the average level, and 168 had an above average income. With regard to education, 113 respondents were high school graduates, while 295 had a college degree. No differences were found between men and women with regard to demographics.

Table 1. Identified attributes of banks.

Variety of services in the bank
Variety of automated services
Efficiency of service
Variety of benefits for current customers
Variety of benefits for new customers
Short waiting time
Courtesy of employees
Personal service
Low commission
Credit framework
Professional service
Accessibility to service
Innovation of service
Recommendation of friends
Reputation of bank
Reliability of bank


In order to reduce the dimensionality of the data and avoid potential collinearity between similar service attributes due to high internal correlations, we conducted a principal component factor analysis. The results of this analysis yielded a three factor solution with the following concepts and percent of variance explained: 1) core bank services, $31.26 \%$; 2) personal service, $20.49 \%$, and 3) cost of service, $11.77 \%$, with a total of $62.27 \%$ variance explained. The full analysis is presented in Appendix F. We used the factor scores of these three factors in the choice model [for further details about the use of factor scores in choice models, see [51].

\subsubsection{The Empirical Model}

The multinomial logit (MNL) model is a simultaneous, compensatory, attribute choice model incorporating the concepts of thresholds, diminishing returns to scale, and saturation levels [47]. For each individual, the MNL estimates the probability of preferring each alternative in the choice set. Furthermore, the MNL is based on the assumption that the overall preference of a consumer for a particular choice, in this case, the preferred banking service, is a function of the perceived relative utility that the choice has for the consumer. The utility function can be separated into: 1) a deterministic component (measured in terms of the perceived value of the attributes of the alternative) and 2) a random error component, which is independent and identically distributed across all individuals with a Weibull distribution. In addition, it can provide diagnostic information regarding the salient attributes involved in the preference process.

Let $U_{i j}$ be the utility of alternative product $j$ for customer $i$, and $J$ the number of alternative products. We can separate the utility function into a deterministic component $V_{i j}$ (measured in terms of the perceived value associated with the characteristics of the products), and an unobserved random component, $\varepsilon_{i j}$, which is independent and identically distributed such that

$$
U_{i j}=V_{i j}+\varepsilon_{i j}
$$

where $V_{i j}$ is the deterministic component of utility of an individual i $(i=1,2, \cdots, n)$ when choosing alternative $j(j=1,2, \cdots, m)$ and $\varepsilon_{i j t}$ is the random component of utility. Thus, the probability $P_{i j}$ that an alternative brand $j$ will be chosen from a set of alternatives $\mathrm{j}$ depends only on the deterministic component of the utility function, such that $P_{i j}=\operatorname{Pr}\left[U_{i j=J} \geq U_{i j \neq J}, \forall, \in C_{j}\right]$, and

$$
P_{i j}=\frac{\exp \left(V_{i j}\right)}{\sum_{j=1}^{j=m} \exp \left(V_{i j}\right)}
$$

where $V_{i j}=\sum_{k=1}^{k} \alpha_{k} x_{i j k}, \quad \alpha_{k}$ is the importance of the attribute $k^{\text {th }}$ in the utility, and $x_{i j k}$ is the rating of consumer $\mathrm{i}$ of attribute $\mathrm{k}$ for alternative $j$.

\subsubsection{Utility Specification}

The deterministic component of the utility function has the following form:

$$
V_{i j}=\alpha_{1} \text { Core Service }_{i j}+\alpha_{2} \text { Personal Service }_{i j}+\alpha_{3} \text { Cost }_{i j}
$$


where Core Service $_{i j}$ refers to consumer $i$ s perceptions of the core services of bank $j$, Personal Service $_{i j}$ refers to consumer is perceptions of the personal service of bank $j$, Cost $t_{i j}$ is consumer $i$ s perceptions of the cost associated with the services of bank $j$, and $\alpha_{1}, \alpha_{2}, \alpha_{3}$ are the parameters to estimate.

\subsection{Experimental Study}

For further validation of the results obtained in the descriptive study, we conducted an online experiment using Prolific Academic site (https://www.prolific.ac) among Americans. One hundred and sixty-nine participants answered the questionnaires, $45 \%$ men and 55\% women (in treatment one-49 men, 60 women; in treatment two- 27 men, 33 women). The mean age was 32.14 years $(S D=10.36)$. With regard to marital status, $61 \%$ were single, $27 \%$ were married and $12 \%$ were in another status. Regarding gross annual income, $25 \%$ earned up to $\$ 10,000,21 \%$ earned $\$ 10,001-\$ 25,000,32 \%$ earned $\$ 25,001-\$ 50,000,14 \%$ earned $\$ 50,001-\$ 100,000,7 \%$ earned $\$ 100,001-\$ 150,000$ and $0.6 \%$ earned more than $\$ 150,000$ a year. With regard to education, $40 \%$ had a high school education, $39 \%$ had a BA, $14 \%$ an $\mathrm{MA}, 4 \%$ a $\mathrm{PhD}$ and $4 \%$ had another kind of education. No differences were found between men and women demographically. A 2 (gender: men and women) by 2 (treatment one-high cost \& low level of personal service/treatment two-low cost $\&$ high level of personal service) experiment was designed to investigate whether the likelihood of remaining with a bank would differ in the following two situations based on gender.

High cost and a low level of personal service. You have had your account in the same bank for the past couple of years. You are quite satisfied with the basic core services of your bank and with the personal service you receive from the employees and the manager when coming to the bank. But in comparison to other similar banks in your area, the waiting time for service and the commissions you are being charged are relatively high.

Low cost and a high level of personal service. You have had your account in the same bank for the past couple of years. You are quite satisfied with the basic core services of your bank and you are not satisfied with the personal service you receive from the employees and manager of the bank when coming to the bank. But in comparison to other similar banks in your area, the waiting time for service and the commissions you are being charged are low.

The respondents were asked to rate their likelihood of remaining with their current bank on a scale ranging from 1-not likely at all to 7-very likely. We asked the questions about demographics after the respondents indicated their responses to the two scenarios.

\section{Results}

\subsection{Descriptive Study}

Table 2 presents the estimates for the three attributes-core services, personal service and cost-in predicting the probability of choosing a particular bank. 
Table 2. Estimates of aggregate and gender segmented models.

\begin{tabular}{ccccccc}
\hline & \multicolumn{2}{c}{ All } & \multicolumn{2}{c}{ Female } & \multicolumn{2}{c}{ Male } \\
\hline & Coefficient & P-value & Coefficient & P-value & Coefficient & P-value \\
Core services & 1.4697 & 0.0000 & 1.1435 & 0.0000 & 1.9523 & 0.0000 \\
Personal service & 0.5888 & 0.0000 & 0.4492 & 0.0000 & 0.7793 & 0.0000 \\
Low cost & 0.2614 & 0.0053 & 0.0984 & 0.4065 & 0.5130 & 0.0003 \\
N & 408 & & 195 & & 213 & \\
McFadden R2 & 0.2576 & & 0.2031 & & 0.3303 & \\
LL & -487.5007 & & -250.0914 & & -229.5857 & \\
\hline
\end{tabular}

As the table illustrates, cost was significant only for men, supporting H1. Personal service was significant for both men and women, hence $\mathrm{H} 2$ was not confirmed. Finally, core services were important for both genders.

To determine whether the segmentation by gender was meaningful or whether the population was homogeneous, we followed Gensch's suggestion [51] to examine possible segments by comparing the fit indices of the aggregate model to that of the segmented model using a log likelihood test: , where. The resulting $\chi^{2}$ value of -15.6472 is distributed and significant at the 0.05 level, validating the appropriateness of this segmentation scheme.

\subsection{Experimental Study}

Differences in gender were significant only in scenario 1 where personal service was satisfactory, but the bank's costs were high. In this situation, women were more likely than men to remain with the bank (Men: Mean $=4.12 \mathrm{SD}=1.83$; Women: Mean $=4.77$ $\mathrm{SD}=1.407$, sig $=0.046)$. In scenario 2 where personal service was unsatisfactory, but the bank's costs were low, there was no difference between men and women in the decision to stay with the bank (Men: Mean $=2.63 \mathrm{SD}=1.08$; Women: Mean $=3.21 \mathrm{SD}=$ 1.59 , N.S).

\section{Discussion}

In light of the conflicting and ambiguous findings regarding gender differences in the selection criteria of banks, the objective of this research was to examine differences between men and women when they had to actually choose a specific bank. Our findings provide some support for the predictions of the evolutionary theory that men as past hunters will be more focused on instrumental and practical attributes such as cost, and women as past gatherers are more contextual and include experiential attributes such as personal service in their considerations. One explanation for the similarity of the importance of personal service among men and women comes from Stafford's findings [33] that men tend to place more value on personal recognition and attention (e.g., being catered to as important individuals who are knowledgeable and competent with respect to financial decision-making) than women. Personal service may include not only elements of relational or interpersonal communication, but also of ego gratification. 
Furthermore, as Berger and colleagues [52] noted, it "pays" to have friends. Given that executive bank appointments are tied to social ties; such personal service might serve as an instrumental utility. As Kahn \& Kahn [53] maintained, impression management might influence men's purchases of a brand more than women's. Evolutionary theory explains this male tendency as a way to signal their financial resources to women and other potential male rivals [54] [55]. This explanation might clarify the importance of personal service for women as a relational experience and for men as an impression management technique.

\section{Implications and Conclusions}

These results add to our theoretical understanding of the role that gender plays in making choices that involve the consideration of a variety of factors. Our findings suggest that marketing managers of banks should not try to appeal to the aggregate market by emphasizing a single financial benefit for all customers. Instead, they would do well to target such appeal only for men and save ineffective resources when targeting also women (advertisement in Appendix A, Appendix B and Appendix C would be effective for targeting men only). Using an undifferentiated strategy for men and women will be effective when focusing on the core benefits of the service or on personal interactions with customers (presumably with a focus on different aspects of personal service for each gender). Moreover, targeting only women with appeals that highlight personal service (as presented in Appendix D) is not recommended, because this dimension is apparently equally important for both genders. Future research should further examine the personal service dimension in all its aspects to determine whether relational, interaction benefits are more important to women and attention and recognition are more important to men.

This study investigates a particular type of service. Future research can extend this approach into other service categories, such as visiting a restaurant or purchasing a cellular service, and to other financial services, such as credit card services, to determine whether there is a similar pattern of saliency. Doing so would strengthen the validity of our contention that evolutionary differences in men and women are the reason for the differences observed in the process of choosing a bank.

\section{References}

[1] Mokhlis, S. (2009) Determinants of Choice Criteria in Malaysia's Retail Banking, an Analysis of Gender-Based Choice Decisions. European Journal of Economics, Finance and Administrative Sciences, 1, 1450-1467.

[2] Almossawi, M. (2001) Bank Selection Criteria Employed by College Students in Bahrain, an Empirical Analysis. International Journal of Bank Marketing, 19, 115-125. http://dx.doi.org/10.1108/02652320110388540

[3] Plank, R., Greene, R. and Greene, J. (1994) Understanding Which Spouse Makes Financial Decisions. Journal of Retail Banking, 16, 21-21.

[4] Ladhari, R. and Leclerc, A. (2013) Building Loyalty with Online Financial Services Customers, Is There a Gender Difference? Journal of Retailing and Consumer Services, 20, 560-569. 
http://dx.doi.org/10.1016/j.jretconser.2013.07.005

[5] Karjaluoto, H., Cruz, P., Barretto Filgueiras Neto, L., Muñoz-Gallego, P. and Laukkanen, T. (2010) Mobile Banking Rollout in Emerging Markets, Evidence from Brazil. International Journal of Bank Marketing, 28, 342-371. http://dx.doi.org/10.1108/02652321011064881

[6] Nysveen, H., Pedersen, P.E. and Thorbjørnsen, H. (2005) Explaining Intention to Use Mobile Chat Services, Moderating Effects of Gender. Journal of Consumer Marketing, 22, 247256. http://dx.doi.org/10.1108/07363760510611671

[7] Yu, C. (2012) Factors Affecting Individuals to Adopt Mobile Banking: Empirical Evidence from the UTAUT Model. Journal of Electronic Commerce Research, 13, 104.

[8] Khazeh, K. and Decker, W.H. (1992) How Customers Choose Banks. Journal of Retail Banking, 14, 41-45.

[9] Boyd, W.L., Leonard, M. and White, C. (1994) Customer Preferences for Financial Services: An Analysis. International Journal of Bank Marketing, 12, 9-15.

[10] Darley, W.K. and Smith, R.E. (1995) Gender Differences in Information Processing Strategies: An Empirical Test of the Selectivity Model in Advertising Response. Journal of Advertising, 24, 41-56. http://dx.doi.org/10.1080/00913367.1995.10673467

[11] Montford, W. and Goldsmith, R.E. (2016) How Gender and Financial Self-Efficacy Influence Investment Risk Taking. International Journal of Consumer Studies, 40, 101-106.

http://dx.doi.org/10.1111/ijcs.12219

[12] Wilson, E. (1975) Sociobiology: The New Synthesis. Belknap, Cambridge.

[13] Lowe, M. (1978) Sociobiology and Sex Differences. Signs, 4, 118-125. http://dx.doi.org/10.1086/493572

[14] Saad, G. and Gill, T. (2000) Applications of Evolutionary Psychology in Marketing. Psychology and Marketing, 17, 1005-1034.

[15] Meyers-Levy, J. and Maheswaran, D. (1991) Exploring Differences in Males' and Females' Processing Strategies. Journal of Consumer Research, 18, 63-70. http://dx.doi.org/10.1086/209241

[16] Fisher, H.E. (1999) The First Sex: The Natural Talents of Women and How They Will Change the World. Random House, New York.

[17] Miller, J. (1991) The Development of Women's Sense of Self. In: Jordan, J.V., Kaplan, A.B., Miller, J.B., Stiver, I.P. and Surrey, J.L., Eds., Woman's Growth in Connection: Writings from the Stone Center, Guildford Press, New York.

[18] Van Slyke, C., Comunale, C.L. and Belanger, F. (2002) Gender Differences in Perceptions of Web-Based Shopping. Communications of the ACM, 45, 82-86. http://dx.doi.org/10.1145/545151.545155

[19] Walsh, G., Mitchell, V.W. and Hennig-Thurau, T. (2001) German Consumer DecisionMaking Styles. Journal of Consumer Affairs, 35, 73-95. http://dx.doi.org/10.1111/j.1745-6606.2001.tb00103.x

[20] Fischer, E. and Arnold, S.J. (1994) Sex, Gender Identity, Gender Role Attitudes, and Consumer Behavior. Psychology and Marketing, 11, 163-182.

http://dx.doi.org/10.1002/mar.4220110206

[21] Bakewell, C. and Mitchell, V.W. (2003) Generation Y Female Consumer Decision-Making Styles. International Journal of Retail \& Distribution Management, 31, 95-106. http://dx.doi.org/10.1108/09590550310461994

[22] Holbrook, M.B. (1986) Aims, Concepts, and Methods for the Representation of Individual Differences in Esthetic Responses to Design Features. Journal of Consumer Research, 13, 
337-347. http://dx.doi.org/10.1086/209073

[23] Silverman, I. and Eals, M. (1990) Sex Differences in Spatial Abilities: Evolutionary Theory and Data. International Society for Human Ethology, Binghamton.

[24] Meyers-Levy, J. and Sternthal, B. (1991) Gender Differences in the Use of Message Cues and Judgments. Journal of Marketing Research, 28, 84-96.

http://dx.doi.org/10.2307/3172728

[25] Canli, T., Desmond, J.E., Zhao, Z. and Gabrieli, J.D.E. (2002) Sex Differences in the Neural Basis of Emotional Memories. Proceedings of the National Academy of Sciences of the United States of America, 99, 10789-10794. http://dx.doi.org/10.1073/pnas.162356599

[26] Gur, R.C., Gunning-Dixon, F., Bilker, W.B. and Gur, R.E. (2002) Sex Differences in Temporo-Limbic and Frontal Brain Volumes of Healthy Adults. Cerebral Cortex, 12, 998-1003. http://dx.doi.org/10.1093/cercor/12.9.998

[27] Burgess, B., Yaoyuneyong, G. and Gibbs, S. (2014) Gender, Self-Construal and Impulse Buying Behavior of Young Thai Consumers. Asian Journal of Business Research, 4, 1-15.

[28] Blyth, D.A., Hill, J.P. and Thiel, K.S. (1982) Early Adolescents' Significant Others: Grade and Gender Differences in Perceived Relationships with Familial and Nonfamilial Adults and Young People. Journal of Youth and Adolescence, 11, 425-450. http://dx.doi.org/10.1007/BF01538805

[29] Burke, R.R. (2002) Technology and the Customer Interface: What Consumers Want in the Physical and Virtual Store. Journal of the Academy of Marketing Science, 30, 411. http://dx.doi.org/10.1177/009207002236914

[30] Beutel, A.M. and Marini, M.M. (1995) Gender and Values. American Sociological Review, 60, 436-448. http://dx.doi.org/10.2307/2096423

[31] Buser, T. (2012) The Impact of the Menstrual Cycle and Hormonal Contraceptives on Competitiveness. Journal of Economic Behavior \& Organization, 83, 1-10. http://dx.doi.org/10.1016/j.jebo.2011.06.006

[32] Wozniak, D., Harbaugh, W.T. and Mayr, U. (2014) The Menstrual Cycle and Performance Feedback Alter Gender Differences in Competitive Choices. Journal of Labor Economics, 32, 161-198. http://dx.doi.org/10.1086/673324

[33] Stafford, M.R. (1996) Demographic Discriminators of Service Quality in the Banking Industry. Journal of Services Marketing, 10, 6-22. http://dx.doi.org/10.1108/08876049610124554

[34] Laroche, M., Rosenblatt, J.A. and Manning, T. (1986) Services Used and Factors Considered Important in Selecting a Bank: An Investigation across Diverse Demographic Segments. International Journal of Bank Marketing, 4, 35-55. http://dx.doi.org/10.1108/eb010771

[35] Aregbeyen, O. (2011) The Determinants of Bank Selection Choices by Customers: Recent And Extensive Evidence From Nigeria. International Journal of Business and Social Science, 2, 276-288.

[36] Lee, H.J., Cho, H.J., Xu, W. and Fairhurst, A. (2010) The Influence of Consumer Traits and Demographics on Intention to Use Retail Self-Service Checkouts. Marketing Intelligence \& Planning, 28, 46-58. http://dx.doi.org/10.1108/02634501011014606

[37] Ukenna, S. and Monanu, O.G. (2012) Analysis of the Influence of Gender on the Choice of Bank in Southeast Nigeria. International Journal of Business and Management, 7, 230-241. http://dx.doi.org/10.5539/ijbm.v7n3p230

[38] Omar, O. and Orakwue, E. (2006) Gender-Based Choice of Retail Banking in Nigeria. Journal of Business \& Retail Management Research, 1, 20-31. 
[39] Narteh, B. and Owusu-Frimpong, N. (2011) An Analysis of Students' Knowledge and Choice Criteria in Retail Bank Selection in Sub-Saharan Africa: The Case of Ghana. International Journal of Bank Marketing, 29, 373-397. http://dx.doi.org/10.1108/02652321111152909

[40] Srivatsa, H. and Srinivasan, R. (2008) Gender Based Banking Psychographics: An Indian Empirical Study. International Journal of Business Research, 8, 88-95.

[41] VasanthaKumari, H. and Rani, S.S. (2011) An Empirical Analysis of Gender Based Choice Criteria in Retail Banking-Among Software Professionals. Data Mining and Knowledge Engineering, 3, 749-755.

[42] Tan, C.T. and Chua, C. (1986) Intention, Attitude and Social Influence in Bank Selection: A Study in an Oriental Culture. International Journal of Bank Marketing, 4, 43-53. http://dx.doi.org/10.1108/eb010783

[43] Devlin, J.F. (2002) An Analysis of Choice Criteria in the Home Loans Market. International Journal of Bank Marketing, 20, 212-226. http://dx.doi.org/10.1108/02652320210437661

[44] Katircioglu, S.T., Tumer, M. and Kılınç, C. (2011) Bank Selection Criteria in the Banking Industry: An Empirical Investigation from Customers in Romanian Cities. African Journal of Business Management, 5, 5551-5558.

[45] Fisher, R.J. (1993) Social Desirability Bias and the Validity of Indirect Questioning. Journal of Consumer Research, 20, 303-315. http://dx.doi.org/10.1086/209351

[46] Lowengart, O. (2010) Heterogeneity in Consumer Sensory Evaluation as a Base for Identifying Drivers of Product Choice. JBM, 37, 37-50.

[47] McFadden, D. (1973) Conditional Logit Analysis of Qualitative Choice Be. In: Zarembka, P., Ed., Frontiers in Econometrics, Academic Press, New York, 105-142.

[48] McFadden, D. (1980) Econometric Models for Probabilistic Choice among Products. Journal of Business, 53, S13-S29. http://dx.doi.org/10.1086/296093

[49] McFadden, D. (1986) The Choice Theory Approach to Market Research. Marketing Science, 5, 275-297. http://dx.doi.org/10.1287/mksc.5.4.275

[50] Mavr, I.M. and Ioannou, G. (2006) Consumers' Perspectives on Online Banking Services. International Journal of Consumer Studies, 30, 552-560. http://dx.doi.org/10.1111/j.1470-6431.2006.00541.x

[51] Gensch, D.H. and Ghose, S. (1992) Elimination by Dimensions. Journal of Marketing Research, 29, 417-429. http://dx.doi.org/10.2307/3172708

[52] Berger, A.N., Kick, T., Koetter, M. and Schaeck, K. (2013) Does It Pay to Have Friends? Social Ties and Executive Appointments in Banking. Journal of Banking \& Finance, 37, 20872105. http://dx.doi.org/10.1016/j.jbankfin.2013.01.040

[53] Khan, G. and Khan, N. (2011) Gender Differences in Susceptibility to Normative Social Influence on the Purchase Decisions of Designer Label Apparel. International Business \& Economics Research Journal, 7, 11-57.

[54] Saad, G. and Vongas, J.G. (2009) The Effect of Conspicuous Consumption on Men's Testosterone Levels. Organizational Behavior and Human Decision Processes, 110, 80-92. http://dx.doi.org/10.1016/j.obhdp.2009.06.001

[55] Sundie, J.M., Kenrick, D.T., Griskevicius, V., Tybur, J.M., Vohs, K.D. and Beal, D.J. (2011) Peacocks, Porsches, and Thorstein Veblen: Conspicuous Consumption as a Sexual Signaling System. Journal of Personality and Social Psychology, 100, 664-680.

http://dx.doi.org/10.1037/a0021669 
Appendix A

We Have The Best Business Checking Deal Around: Take A Look.

\begin{tabular}{|c|c|c|c|c|c|}
\hline Bank & $\begin{array}{l}\text { Monthly } \\
\text { service } \\
\text { charge }\end{array}$ & $\begin{array}{l}\text { Balance requirements to avoid } \\
\text { monthly service charge? }\end{array}$ & $\begin{array}{l}\text { Monthly } \\
\text { transaction } \\
\text { allowance? }\end{array}$ & $\begin{array}{l}\text { Per-item fee } \\
\text { over monthly } \\
\text { transaction } \\
\text { allowance? }^{2}\end{array}$ & $\begin{array}{l}\text { Switch to Columbia Bank } \\
\text { and each year you } \\
\text { could save up to: }\end{array}$ \\
\hline $\begin{array}{c}\text { Columbia Bank } \\
\text { FREE Small } \\
\text { Business Checking }\end{array}$ & NONE & NONE & 1,000 & $\$ 0.00$ & $\begin{array}{l}\text { Save up to } \\
\$ 744 \\
\text { or more! }\end{array}$ \\
\hline TD $\begin{array}{c}\text { TD Bank } \\
\text { Simple Checking }\end{array}$ & $\$ 8$ & Monthly service charge always charged. & 200 & S0.75 & $\$ 546$ \\
\hline $\begin{array}{l}\text { Bank of America } \\
\text { Business } \\
\text { Fundamentals }{ }^{\top M}\end{array}$ & $\$ 18$ & $\begin{array}{l}\$ 3,000 \text { minimum daily balance OR } \$ 5,000 \text { average } \\
\text { monthly balance OR } \$ 15,000 \text { combined average } \\
\text { monthly balance of linked accounts OR } \$ 250 \text { each } \\
\text { month in newpurchases on a business debit or } \\
\text { credit card. }\end{array}$ & 200 & $\$ 0.45$ & $\$ 486$ \\
\hline $\begin{array}{l}\text { Chase } \\
\text { Total Business } \\
\text { Checking }^{511}\end{array}$ & $\$ 12$ & $\begin{array}{l}\$ 1,500 \text { minimum daily balance OR } \\
\text { maintain a linked Chase Private Client } \\
\text { Checking or Premier Platinum Checking } \\
\text { personal checking account. }\end{array}$ & 200 & $\$ 0.40$ & $\$ 384$ \\
\hline $\begin{array}{l}\text { Wells Fargo } \\
\text { Business } \\
\text { Checking }{ }^{\circledR}\end{array}$ & $\$ 12$ & $\begin{array}{l}\$ 3,000 \text { minimum daily balance OR } \$ 6,000 \\
\text { average ledger balance OR have a Wells } \\
\text { Fargo Business Payroll Service transaction } \\
\text { vfrom this account each month. }\end{array}$ & 150 & $\$ 0.50$ & $\$ 744$ \\
\hline
\end{tabular}

http://www.columbiabankonline.com/home/business/checking

Appendix B

\begin{tabular}{|c|c|c|c|}
\hline & They Say & You Pay & Actual Fee \\
\hline HSBC $\longrightarrow$ & $E 4$ & $£ 34.09$ & $3.4 \%$ \\
\hline LLOYDS BANK & E10 & E 34.72 & $3.5 \%$ \\
\hline \& NatWest & E10 & $£ 50.66$ & $5.1 \%$ \\
\hline 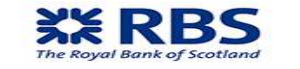 & E10 & E50.58 & $5.1 \%$ \\
\hline$\$$ Santander & $E 25$ & E54.01 & $5.4 \%$ \\
\hline \multirow[t]{2}{*}{ 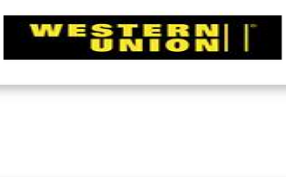 } & FREE & $£ 43.61$ & $4.4 \%$ \\
\hline & We Say & You Pay & Our Fee \\
\hline Transferwi & $E 5$ & $E 5$ & $0.5 \%$ \\
\hline
\end{tabular}

https://transferwise.com/blog/2014-06/sir-richard-branson-joins-our-mission-to-stamp -out-hidden-fees/. 
Appendix C

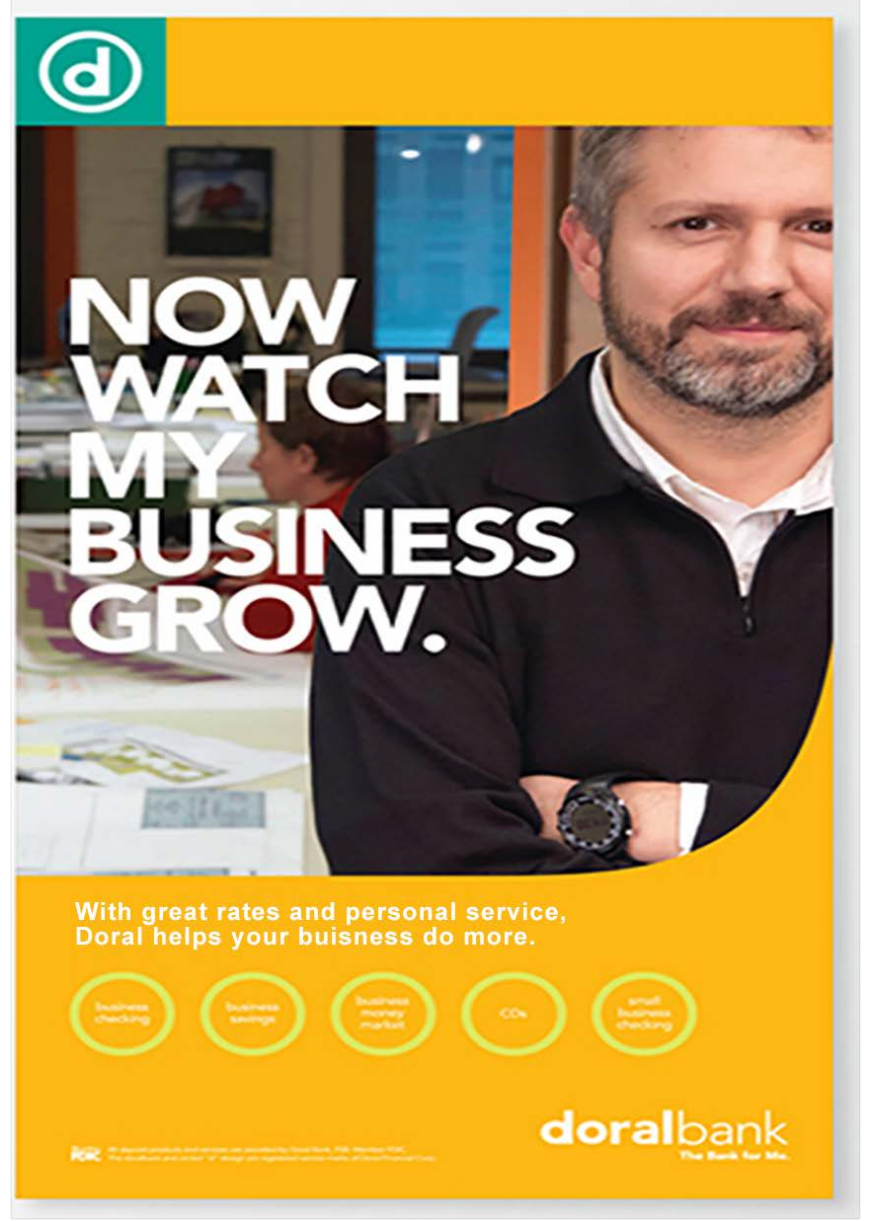

Appendix D
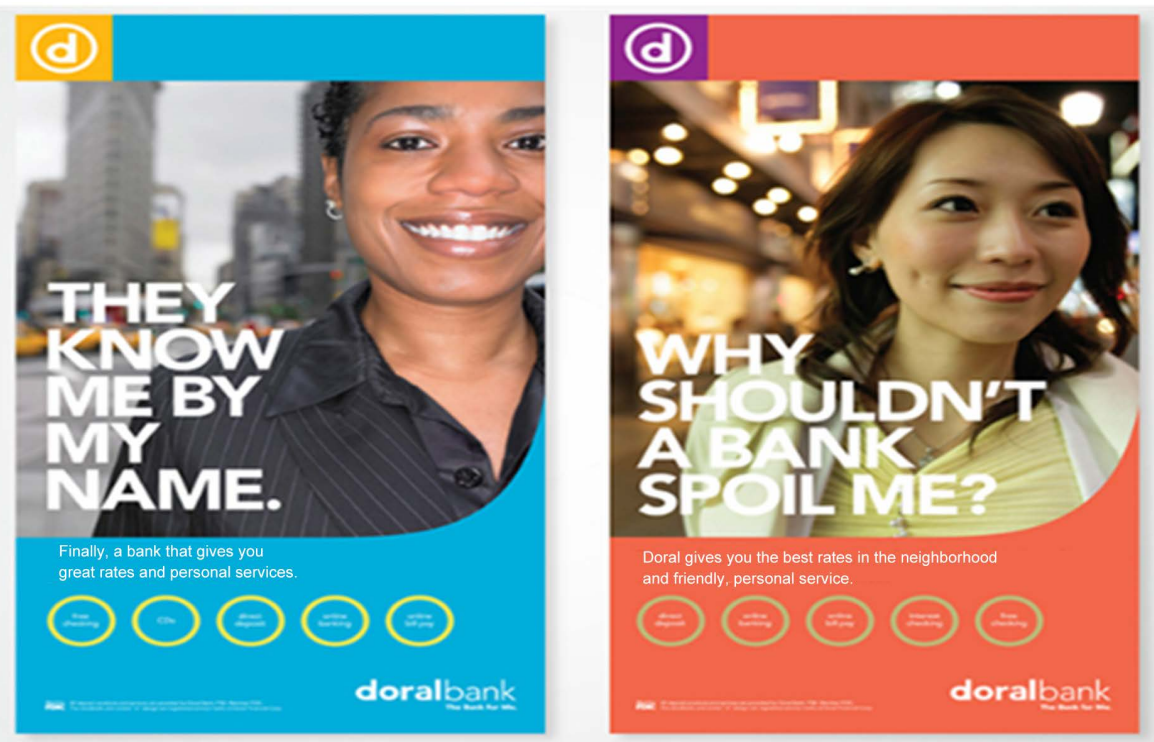


\section{Appendix E. Questions on Bank Attributes}

How would you rate the attributes below with regard to Bank L/P/D/M/B as you perceive them on a scale of 1 to 7 , where 1 represents the lowest level of the attribute and 7 the highest.

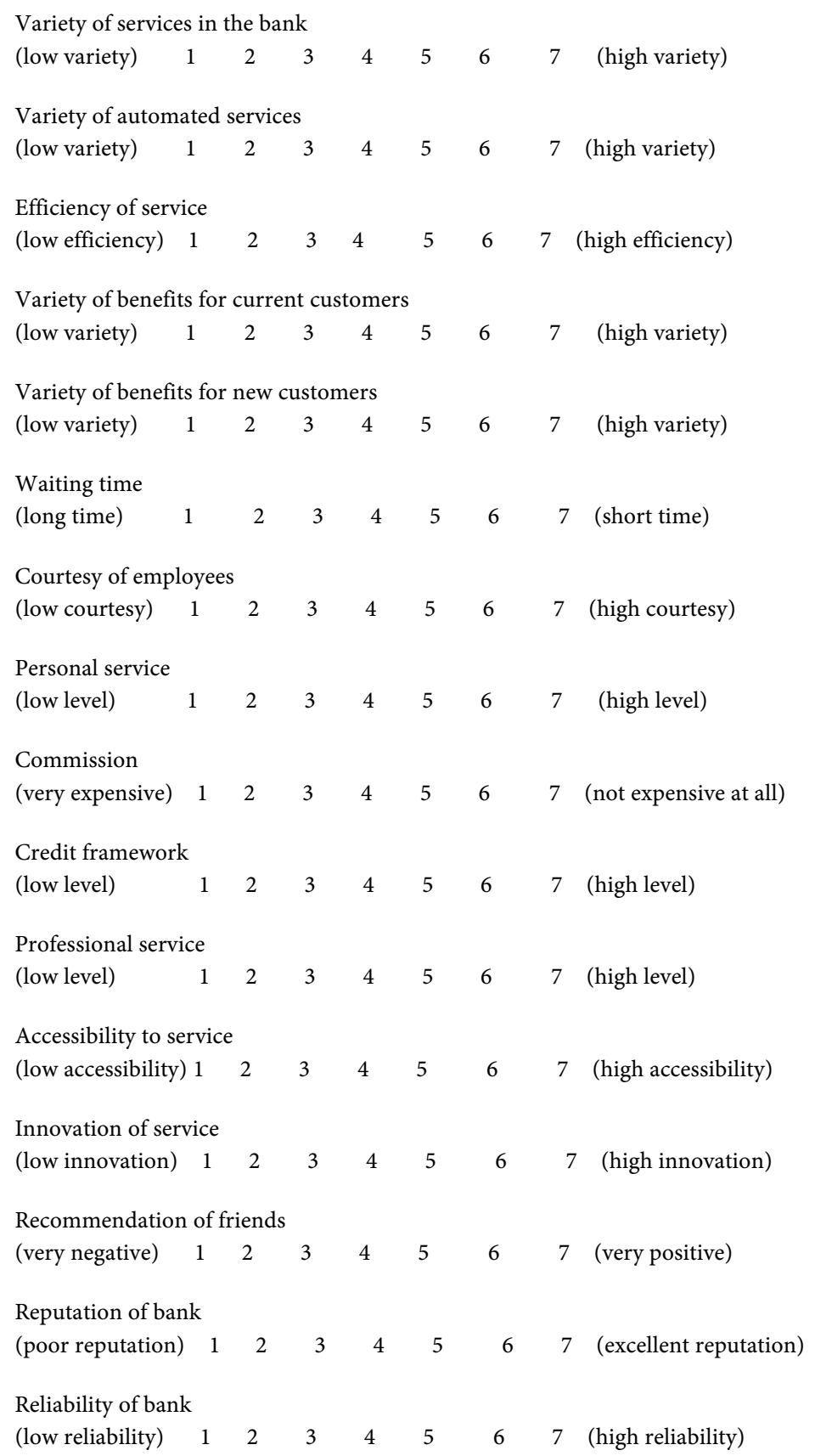




\section{Appendix F. Results of Factor Analysis}

\begin{tabular}{|c|c|c|c|}
\hline Attribute & Core services & Personal service & Low cost \\
\hline Variety of services in the bank & 0.792 & & \\
\hline Variety of automated services & 0.810 & & \\
\hline Efficiency of service & 0.548 & & \\
\hline Variety of benefits for current customers & & 0.505 & \\
\hline Variety of benefits for new customers & 0.519 & & \\
\hline Short waiting time & & & 0.757 \\
\hline Courtesy of employees & & 0.748 & \\
\hline Personal service & & 0.838 & \\
\hline Low commission & & & 0.758 \\
\hline Credit framework & & 0.523 & \\
\hline Professional service & & 0.591 & \\
\hline Accessibility to service & 0.680 & & \\
\hline Innovation of service & 0.717 & & \\
\hline \multicolumn{4}{|l|}{ Recommendation of friends } \\
\hline Reputation of bank & 0.746 & & \\
\hline Reliability of bank & 0.717 & & \\
\hline$\%$ variance & $31.26 \%$ & $20.249 \%$ & $11.769 \%$ \\
\hline
\end{tabular}

We categorized these factors into three groups that explained $63.277 \%$ of the variance in the responses.

\section{Submit or recommend next manuscript to SCIRP and we will provide best service} for you:

Accepting pre-submission inquiries through Email, Facebook, LinkedIn, Twitter, etc. A wide selection of journals (inclusive of 9 subjects, more than 200 journals)

Providing 24-hour high-quality service

User-friendly online submission system

Fair and swift peer-review system

Efficient typesetting and proofreading procedure

Display of the result of downloads and visits, as well as the number of cited articles

Maximum dissemination of your research work

Submit your manuscript at: http://papersubmission.scirp.org/

Or contact jssm@scirp.org 